\title{
IMPACT OF PANDEMIC COVID 19 ON THE ECONOMIC CONDITION AND STANDARD OF LIVING AMONG THE PEOPLE OF THOOTHUKUDI DISTRICT
}

\author{
Dr.T.Priyanka1, Ms.A.Amora ${ }^{2}$ \\ Assistant Professor in Commerce, St.Mary's College (Autonomous) Thoothukudi ${ }^{1,2}$
}

\begin{abstract}
The pandemic Covid 19 has totally collapsed the standard of living and economic condition of all the people all around the world. The lock down under gone among the people really it was a challenge to run their daily lives. People lost their life and living due to this Covid. Therefore the researchers of this paper have made an attempt to study the economic condition and the standard of living of the people in Thoothukudi district. For this study 120 respondents was selected at random. Questionnaire were framed and collected among the respondents.
\end{abstract}

Keywords : Pandemic Covid, Standard of Living, Economic Condition

\section{INTRODUCTION}

The economic impact of 2020 corona virus pandemic in India has been largely disruptive. Within a month unemployment rose from $6.7 \%$ on March to $26 \%$ on $19^{\text {th }}$ April 2020. During Lockdown, an estimated 14 crores (140 million) people lost employment. More than $45 \%$ of household across the nation have reported an income drop as compared to previous year. Those in the informal sectors daily wages groups are the most at risk ${ }^{1}$. A large number of framers, fishermen's, saltpan workers and daily coolies around the country who grow perishables are also facing uncertainty ${ }^{2}$. Thoothukudi - one of the leading edible salt producers in the country. A decline in the export orders, owing to the pandemic scare, has created a cascading effect, evaporating the sales and profits of the various industries in Thoothukudi. Likewise there are people in Thoothukudi who are engaged in earning daily wages and fishermen who earn daily wages to run their family. All of a sudden due to this Covid 19 the people has experienced a huge financial barriers to run their daily lives they lost their job, their earning, food and their livelihood. They are in difficult situation to run their day to day life. Therefore the researchers of the study has decided to assess how the people of Thoothukudi district is suffering to run the daily live and the problems faced by them to meet all the economic burden during this lockdown of pandemic Covid 19.

\section{STATEMENT OF THE PROBLEM}

The Corona virus outbreak, which was first detected in China, has infected people in 185 countries. Its spread has left businesses around the world counting the costs. Not only business of the countries but the economically backward people does suffer from various situations. The people earning daily wages, coolies, framers and fisher folk and salt pan workers and many others have lost their living due this pandemic Covid 19. IMF estimate, the expected increase in the share of people living in extreme poverty will range from 0.8 per cent to 1.5 percentage points. This is equivalent to an increase of between 50 million to 70 million people compared with the original estimates for 2020 . Therefore keeping this in mind the researcher has made an attempt to find the economic conditions and the living standard of the economically backward people of Thoothukudi District.

\section{OBJECTIVE OF THE STUDY}

$>\quad$ To assess the economic condition among the people of Thoothukudi District.

$>\quad$ To find out the standard of living of the people in Thoothukudi District during the pandemic Covid 19.

\section{REVIEW OF LITERATURE}

- International Labor Organization (ILO) 2020, estimated that globally more than 25 million jobs would be threatened due to the spread of corona virus. It is estimated that four out of five people (81\%) in the global workforce of 3.3 billion are currently affected by full or partial workplace closure ${ }^{3}$. 


\section{International Advanced Research Journal in Science, Engineering and Technology}

Vol. 8, Issue 9, September 2021

\section{DOI: 10.17148/IARJSET.2021.8908}

- International Monetary Fund (IMF) 2020. The head of IMF Kristalina Georgieva said the world faced the worst economic crisis since the Great Depression of the 1930s. There are high concerns for low-paid and low skilled informal workers in low and middle income countries, where the industries and services have high proportion of such informal workers, who account for $61 \%$ of the global workforce or 2 billion people and they lack any social protection. This sudden loss of livelihood would be horrifying for them ${ }^{3}$.

- $\quad$ CMIE 2020, report shows a significant fall in jobs and simultaneous significant increase in unemployment rate in March 2020. The unemployment rate stands at 8.7\% in March 2020, which is way higher than government unemployment estimate at a 45 -year high of $6.1 \%$ in $2017-18$. This is the highest unemployment rate since September 2016. The unemployed people have also gone up from 32 million to 38 million during the same period. The situation became further worse as we moved into the lockdown period in the last week of March and the unemployment rate soared to $23.8 \%$. However, it is true that many of them would also not be able to get their jobs back, such as informal workers who involved in casual or contractual work and those who returned to their villages ${ }^{3}$.

\section{METHODOLOGY}

The researcher has selected Thoothukudi district because it is researchers own home town. A maximum of 120 respondents has been decided to be selected for the study purpose using Simple Random Sampling. A structured questionnaire was framed and circulated among the respondents. The targeted respondents are the economically backward people (daily coolies, drivers and fisher folk). The researcher has decided to use SPSS Software for analysis.

Table 1 Demographic Characteristic of the Respondents:

\section{RESULTS AND DISCUSSION}

\begin{tabular}{|l|l|l|}
\hline Variable & $\begin{array}{l}\text { No.of } \\
\text { Respondents }\end{array}$ & $\begin{array}{l}\text { Percentage } \\
(\%)\end{array}$ \\
\hline SEX: & & \\
\hline Male & 84 & 70 \\
\hline Female & 36 & 30 \\
\hline Total & 120 & 100 \\
\hline OCCUPATION: & & \\
\hline Fisher folk & 60 & 50 \\
\hline Drivers & 35 & 29.1 \\
\hline Coolies & 25 & 20.8 \\
\hline Total & 120 & 100 \\
\hline INCOME: & & \\
\hline Rs.100-Rs.300 & 35 & 29.1 \\
\hline Rs.301-Rs.600 & 60 & 50 \\
\hline Rs.601-Rs.900 & 20 & 16.6 \\
\hline Above Rs.901 & 5 & 4.1 \\
\hline Total & 120 & 100 \\
\hline
\end{tabular}

Inference: Table 1 demonstrates the Demographic characteristics of the respondents. Majority $70 \%$ of the respondents are male and $30 \%$ are female. The main occupations of most of the respondents (50\%) were fishing and $29.1 \%$ of the respondents are drivers and 20.8 of the respondents are coolies. Majority of the respondents (50\%) earn a daily wages of Rs.301-Rs.600, 29.1\% of the respondents earn a daily wages of Rs.100-Rs.300, 16.6\% of the respondents earn a daily wages of Rs.601-Rs.900 and 4.1\% of the respondents earn a daily wages of Above Rs.901. Therefore majority of the respondents are male and they are engaged in fishing work and they earn a daily wages of Rs.301-Rs.600.

Table 2 Influences of Covid and Lock Down on Economic Conditions

\begin{tabular}{|l|l|l|}
\hline Variable & No.of Respondents & Percentage (\%) \\
\hline Influence of Covid on Economic conditions & & \\
\hline Yes & 120 & 100 \\
\hline No & 0 & 0 \\
\hline Total & 120 & 100 \\
\hline Lock down Stressful & & \\
\hline Yes & 120 & 100 \\
\hline No & 0 & 0 \\
\hline Total & 120 & 100 \\
\hline Ability to meet expenses during Lock down & & \\
\hline
\end{tabular}


International Advanced Research Journal in Science, Engineering and Technology

Vol. 8, Issue 9, September 2021

DOI: $10.17148 /$ IARJSET.2021.8908

\begin{tabular}{|l|l|l|}
\hline Yes & 0 & 0 \\
\hline No & 120 & 100 \\
\hline Total & 120 & 100 \\
\hline Had work like the normal days during lockdown & & \\
\hline Yes & 0 & 0 \\
\hline No & 120 & 100 \\
\hline Total & 120 & 100 \\
\hline Felt Hard to survive during Lock down & & \\
\hline Yes & 120 & 100 \\
\hline No & 0 & 0 \\
\hline Total & 120 & 100 \\
\hline
\end{tabular}

Inference: Table 2 illustrates the influence of Covid and lock down on the economic condition of the respondents. All the respondents $(100 \%)$ responded that there was influence of Covid on Economic conditions and their living, 100\% of the respondents felt that the lock down was Stressful, $100 \%$ of the respondents that they was not able to meet their daily expenses during Lock down, $100 \%$ of the respondents felt that they have no work like the normal days during lockdown and $100 \%$ of the respondents felt Hard to survive during lock down.

Table 3 Hindrances during Covid 19 and Lock Down

\begin{tabular}{|l|l|l|}
\hline Variable & No of Respondent & Percentage (\%) \\
\hline Not able to purchase food materials & & \\
\hline Strongly Agree & 85 & 70.8 \\
\hline No Opinion & 0 & 0 \\
\hline Strongly Disagree & 35 & 29.2 \\
\hline Total & 120 & 100 \\
\hline Scared to go to hospitals & & \\
\hline Strongly Agree & 96 & 80 \\
\hline No Opinion & 0 & 0 \\
\hline Strongly Disagree & 24 & 20 \\
\hline Total & 120 & 100 \\
\hline Not able to go out for normal work or day to day work & & \\
\hline Strongly Agree & 102 & 85 \\
\hline No Opinion & 0 & 0 \\
\hline Strongly Disagree & 18 & 15 \\
\hline Total & 120 & 100 \\
\hline Rise in purchase of grocery and food items & & \\
\hline Strongly Agree & 116 & 96.7 \\
\hline No Opinion & 0 & 0 \\
\hline Strongly Disagree & 4 & 3.3 \\
\hline Total & 120 & 100 \\
\hline Had no earning to run the family & & \\
\hline Strongly Agree & 115 & 95.8 \\
\hline No Opinion & 0 & 0 \\
\hline Strongly Disagree & 5 & 4.5 \\
\hline Total & 120 & 100 \\
\hline & & \\
\hline
\end{tabular}

Inference: Table 3 explains the hindrances during the Covid 19 and lock down. Majority $70.8 \%$ of the respondents have responded that they was not able to purchase food material and $29.2 \%$ of the respondents have strongly disagree the statement. $80 \%$ of the respondents have responded that they were scared to go hospital during pandemic covid and lockdown and $20 \%$ of the respondents have strongly disagreed. $85 \%$ of the respondents felt that they were not able to go out for normal work or day to day work and $15 \%$ have strongly disagreed. $96.3 \%$ of the respondents felt that there is a rise in purchase of grocery and food items and 3.3\% of the respondents have strongly disagreed.95.8 \% of the respondents has felt that there was no earning to run the family during covid and lockdown and $4.5 \%$ of the respondents have strongly disagreed. Therefore from this table 3 it is clear that the respondents have an impact on their standard of living during covid and lockdown. 
DOI: $10.17148 /$ IARJSET.2021.8908

\section{CONCLUSION}

Pandemic covid has destructed many common people living, many have lost their life and others have lost the survival. In this study it was found that, Majority the respondents are male and their main occupations were fishing and they earn a daily wages of Rs.301-Rs.600. the study was focused on drivers and fisher folk and coolies. These respondents felt that they felt hard to survive during this pandemic covid and also because of lockdown implemented throughout the whole state. The people was not able to run a normal life and felt it very difficult to go out from their home. The rise in groceries and products and services during covid and lockdown also had a great impact on the lives of many people. They also lost their work and earning. People was scared to go to hospital for regular check up or even for a fever they were so frightened to approach the hospitals. The survival of the common people became so pathetic. Thus the study has brought that the covid and lockdown had a impact on the people of Thoothukudi district.

\section{REFERENCE}

1. Research centre for Policy, "Podcast: How has India's lockdown impacted unemployment rates and income levels?". Scroll in. Retrieved 24 April 2020.

2. Chaudhry, Siraj A. (26 march 2020). “Covid 19 puts Indias food supply chain to a stress-test”. The Hindu @ businessline. Retrieved 26 March 2020.

3. Times of India (2020). https://timesofindia.indiatimes.com/blogs/red-button-day-light/covid-19-and-the-lockdown-impact-estimating-theunemployment-and-job-losses-in-indias-informal-economy/

4. Menonjyoti Kalita; Golam Imran Hussain. "Determining the Influencing Factors of COVID 19 on Mental Health Using Neural Network". International Research Journal on Advanced Science Hub, 3, Special Issue 6S, 2021, 126-129.

5. Yeshi Ngima; Dorjee Tsering. "Impact of COVID-19 on Education". International Research Journal on Advanced Science Hub, 2, Special Issue ICAMET 10S, 2020, 34-39. doi: 10.47392/irjash.2020.196

6. Siddavatam rammohan reddy; Balaji krushna potnuru. "3D Printing Innovation during Covid-19 Pandemic". International Research Journal on Advanced Science Hub, 2, 8, 2020, 62-67. doi: 10.47392/irjash.2020.95

7. Salini Suresh; Suneetha V; Niharika Sinha; Sabyasachi Prusty. "Latent Approach in Entertainment Industry Using Machine Learning". International Research Journal on Advanced Science Hub, 2, Special Issue ICARD 2020, 2020, 304-307. doi: 10.47392/irjash.2020.106

8. Pooja Dahiya; Roopsi Kaushik; Anil Sindhu. "Corona virus: an Overview Along with Its Alternative Diagnostic Measures". International Research Journal on Advanced Science Hub, 2, Special Issue ICARD 2020, 2020, 163-169. doi: 10.47392/irjash.2020.113

9. Remya S. "Covid19 and Environment-A Theoretical Review from Higher Education Students Perspective". International Research Journal on Advanced Science Hub, 2, Special Issue ICARD 2020, 2020, 227-230. doi: 10.47392/irjash.2020.124 